\title{
Genetic association studies of schizophrenia using the 8p21-22 genes: prepronociceptin (PNOC), neuronal nicotinic cholinergic receptor alpha polypeptide 2 (CHRNA2) and arylamine $\mathrm{N}$-acetyltransferase 1 (NAT1)
}

Ekaterini Blaveri ${ }^{1}$, Gursharan Kalsi ${ }^{1}$, Jacob Lawrence ${ }^{1,3,4}$, Digby Quested ${ }^{5}$, Helen Moorey ${ }^{3,4}$, Graham Lamb ${ }^{3,4}$, Dora Kohen ${ }^{3}$, Raj Shiwach ${ }^{4}$, Utom Chowdhury, ${ }^{3,4}$, David Curtis ${ }^{2}$, Andrew McQuillin ${ }^{1}$, Eva S Gramoustianou ${ }^{1}$ and Hugh MD Gurling*,1

\footnotetext{
${ }^{1}$ Molecular Psychiatry Laboratory, Windeyer Institute of Medical Sciences, Department of Psychiatry and Behavioural Sciences, Royal Free and University College London Medical School, Windeyer Building, 46 Cleveland Street, London W1P 6DB, UK; ${ }^{2}$ Department of Adult Psychiatry, 3rd Floor, Outpatient Building, Royal London Hospital, Whitechapel, London E1 1BB, UK; ${ }^{3}$ Camden and Islington Community Services NHS Trust, St. Lukes Woodside Hospital, Woodside Avenue, London N10 3HU, UK; ${ }^{4}$ The Maudsley Hospital, Camberwell, London SE5 8AF, UK; ${ }^{5}$ Wonneford Hospital, Headington, Oxford OX4 4YE, UK
}

Schizophrenia is a common, genetically heterogeneous disorder with a lifetime prevalence of approximately $1 \%$ in the general population. Linkage studies of affected families have now strongly implicated a susceptibility locus on chromosome 8p21-22. Tests of allelic association with markers on 8p21-22 should be able to localise any quantitative trait nucleotides (QTN's) or susceptibility mutations to within a few hundred kilobases. Three brain expressed candidate susceptibility genes, prepronociceptin (PNOC), neuronal cholinergic receptor, nicotinic, alpha polypeptide 2 (CHRNA2) and arylamine $\mathrm{N}$-acetyltransferase 1 (NAT1) have been mapped to chromosome 8p21-22. A case-control, allelic association study was performed using a novel highly polymorphic dinucleotide repeat, D8S2611 near the PNOC gene, two previously characterised dinucleotide repeats, D8S131 and D8S131P at the CHRNA2 locus and an RFLP at the 3'UTR of the arylamine Nacetyltransferase 1 (NAT1) gene. No differences were found in allele frequencies between the patient and control groups. DNA variations or mutations at or near the three genes under study are unlikely to increase susceptibility to schizophrenia in our population sample. European Journal of Human Genetics (2001) 9, 469-472.

Keywords: polymorphism; D8S2611; neuropeptides; neuronal acetylcholine receptor; candidate gene; schizophrenia

Introduction

Evidence for a susceptibility locus for schizophrenia, mapping to chromosome $8 \mathrm{p} 21-22$ has been reported by

\footnotetext{
*Correspondence: HMD Gurling, Molecular Psychiatry Laboratory, Windeyer Institute for Medical Sciences, Department of Psychiatry and Behavioural Sciences, Royal Free and University College London Medical School, University College London, 46 Cleveland Street, London W1P 6DB, UK. Tel: +4420 7679 9474; Fax: +4420 7679 9437;

E-mail: h.gurling@ucl.ac.uk

Received 10 October 2000; revised 19 February 2001; accepted 23 February 2001
}

several groups. ${ }^{1-3}$ A case control allelic association study was carried out to test the hypothesis that one of three candidate genes localised on chromosome 8p21-22 could be responsible for the increased genetic susceptibility. One of the genes, prepronociceptin (PNOC) precursor encodes at least three biologically active peptides: nocistatin, nociceptin and nocII/III. These biologically active peptides are involved in pain, learning, memory, fear, anxiety, auditory processing, neuroendocrine control, sleep and neuronal development. ${ }^{4}$ The PNOC gene is predominantly transcribed in the brain and spinal cord. The expression pattern and the wide variety of functions make the PNOC gene an 
attractive candidate gene increasing susceptibility to schizophrenia.

The second gene to be studied was the neuronal cholinergic receptor, nicotinic, alpha polypeptide 2 (CHRNA 2 ), which is a member of the neuronal acetylcholine receptor family of multimeric neurotransmitter-gated ion channels. The alpha7 subunit of the neuronal nicotinic receptor (CHRNA7) is considered a candidate gene for the P50 deficit, which is a neurophysiological deficit associated with schizophrenia. ${ }^{5}$ This and the fact that CHRNA2 maps to $8 \mathrm{p} 21,{ }^{6}$ the region implicated by several linkage studies made it a strong candidate.

The third gene to be studied was arylamine N-acetyltransferase 1 (NAT1). There are two genes encoding functional NAT in humans (NAT1 and NAT2) on chromosome 8 p22 within $400 \mathrm{~kb}$ from each other. ${ }^{7}$ Their corresponding proteins are enzymes, which are involved in the metabolism and detoxification of drugs and other foreign chemicals and could be involved in brain pathology through abnormal detoxification, secondarily affecting the brain.

The polymorphisms genotyped at the three candidate loci did not directly affect the function of these genes. It was necessary to find a new polymorphic marker for the PNOC gene to use for genotyping. The human CHRNA2 gene has been positioned exactly at the D8S131 locus and two previously characterised microsatellites at this locus were used. ${ }^{6}$ Finally, a frequent single nucleotide polymorphism at position 1095 of the NAT1 gene was used to test the hypothesis of NAT1 gene involvement. This biallelic polymorphism is a $\mathrm{C} \rightarrow \mathrm{A}$ substitution in the $3^{\prime}$ UTR of the gene and can be detected as a PCR formatted MboII RFLP.

\section{Materials and methods Patients}

One hundred and thirty cases of schizophrenia were studied together with 316 screened normal controls. The cases and controls were all asked if both their parents and grandparents were of Irish, Welsh, Scottish or English ancestry. Those subjects with two or more grandparents who had any other ancestry were excluded but subjects with a single grandparent with a European ancestry were included. After complete description of the study to the subjects, written informed consent was obtained. All affected and unaffected subjects were screened or diagnosed by a psychiatrist using the Lifetime Version of the Schizophrenia and Affective Disorders Schedule (SADS-L). ${ }^{8}$ The cases were rated using the 90-item OPCRIT checklist, ${ }^{9}$ the family history was recorded and a pedigree diagram was drawn. Diagnoses were assigned using Research Diagnostic Criteria. $^{10} 30 \mathrm{ml}$ of blood sample was taken from each individual for DNA analysis. Genomic DNA was extracted using the phenol-chloroform method.

\section{Genotyping}

For the amplification of D8S2611 the oligonucleotide primers mentioned in the previous section (N13F and $\mathrm{N} 13 \mathrm{R})$ were used. Cycle conditions were $95^{\circ} \mathrm{C}$ for $5 \mathrm{~min}$, then 30 cycles of $95^{\circ} \mathrm{C}$ for $30 \mathrm{~s}, 56^{\circ} \mathrm{C}$ for $30 \mathrm{~s}$, and $72^{\circ} \mathrm{C}$ for $30 \mathrm{~s}$, with a final extension step of $7 \mathrm{~min}$ at $72^{\circ} \mathrm{C}$.

For the CHRNA2 gene, subjects were genotyped for microsatellite markers D8S131 (cos132C2) (GDB Amplimer: 215525) and D8S131P (GDB Amplimer: 215528) by PCR. Amplification of D8S131 (cos132C2) marker was achieved using primers 5' AGG GGA TCA GGG CTC AGC A 3' and 5' ATA GGC TGG AGA GTC ACA GG 3'. The amplification conditions were $95^{\circ} \mathrm{C}$ for $5 \mathrm{~min}$, then 30 cycles of $95^{\circ} \mathrm{C}$ for $40 \mathrm{~s}, 60^{\circ} \mathrm{C}$ for $40 \mathrm{~s}$, and $72^{\circ} \mathrm{C}$ for $40 \mathrm{~s}$, with a final extension step of $7 \mathrm{~min}$ at $72^{\circ} \mathrm{C}$. D8S131P was amplified with oligonucleotide primers 5' GCC CCC CAA CAC GGT CTT A 3' and 5' CTT GCT GGA CTT GGA ATG CC 3'. The cycling conditions were $95^{\circ} \mathrm{C}$ for $5 \mathrm{~min}$, then 30 cycles of $95^{\circ} \mathrm{C}$ for $1 \mathrm{~min}, 58^{\circ} \mathrm{C}$ for $30 \mathrm{~s}$, and $72^{\circ} \mathrm{C}$ for $2 \mathrm{~min}$, with a final extension step of $7 \mathrm{~min}$ at $72^{\circ} \mathrm{C}$.

All PCRs for the microsatellite markers were performed in a volume of $12.5 \mu \mathrm{l}$, containing: $100 \mathrm{ng}$ genomic DNA, $10 \mathrm{~mm}$ Tris-Cl (pH 8.4), $50 \mathrm{mM} \mathrm{KCl,} 1.5 \mathrm{~mm} \mathrm{MgCl}_{2}, 200 \mu \mathrm{M}$ dNTPs, $2.0 \mathrm{pmol}$ of $\left[{ }^{32} \mathrm{P}\right]$ end-labelled forward primer and a nonlabelled reverse primer, and 0.2 units of Taq polymerase (Qiagen) in a Gene Amp 9700 System (Perkin Elmer Cetus, Palo Alto, CA, USA). The PCR products were mixed with an equal volume of formamide buffer and denatured at $95^{\circ} \mathrm{C}$ for 3 min. The alleles were separated on $6 \%$ denaturing polyacrylamide gels (National Diagnostics Ltd). Products were detected by autoradiography.

The method used to genotype the NAT1 polymorphism is a modification of the method described by Bell et $a l^{11}$ and Payton et al. ${ }^{12}$ Primers N769 (F): 5' ACT CTG AGT GAG GTA GAA ATA 3' and N1113 (R): 5' ACA GGC CAT CTT TAG AA3' were used to PCR amplify the RFLP. The N1113 primer contains a partial MboII restriction site, which forms a complete site when a $\mathrm{C}$ is at position 1095 instead of an A. PCR reactions were performed in a volume of $12.5 \mu \mathrm{l}$ containing: $100 \mathrm{ng}$ of genomic DNA, 20 pmoles of each primer, $200 \mu \mathrm{M}$ dNTPs, $10 \mathrm{~mm}$ Tris-Cl (pH 8.4), $50 \mathrm{~mm} \mathrm{KCl}$, $2.0 \mathrm{mM} \mathrm{MgCl}_{2}$ and 0.5 units of Taq DNA polymerase (Qiagen). Reactions were incubated at $95^{\circ} \mathrm{C}$ for $5 \mathrm{~min}$ followed by 30 cycles of denaturing for $30 \mathrm{~s}$ at $95^{\circ} \mathrm{C}$, annealing for $30 \mathrm{~s}$ at $52^{\circ} \mathrm{C}$ followed by extension at $68^{\circ} \mathrm{C}$ for $30 \mathrm{~s}$. Amplification was completed by incubation at $68^{\circ} \mathrm{C}$ for $7 \mathrm{~min}$. The PCR products were digested overnight at $37^{\circ} \mathrm{C}$ with three units of MboII (Promega, UK) and separated by electrophoresis through $4.0 \%$ Metaphor agarose (FMC Bioproducts) gels.

\section{Statistical analysis}

Allelic association between the disease and marker loci was tested by the computer program CLUMP, which is designed for use in genetic case-control association studies. ${ }^{13}$ CLUMP 
assesses the significance of the departure of observed values from the expected values in a $2 \times \mathrm{N}$ contingency table conditional on marginal totals. A $\chi^{2}$ value is produced and the significance level is assessed using a Monte Carlo approach, which produces an empirical P-value. This approach deals well with statistical difficulties produced when highly polymorphic markers are used in the study. Linkage disequilibrium between alleles at the marker loci was estimated by the computer program $\mathrm{EH}^{14}$

\section{Results}

Identification of a novel microsatellite repeat (D8S2611) A human genomic clone (122n11) containing the prepronociceptin gene was identified from the PAC human genomic library-RPCI $1^{15}$ by screening with the polymerase chain reaction (PCR) using primer sequences derived from the $3^{\prime}$ portion of the PNOC gene. ${ }^{16}$ The primers used were: Forward primer: 5'GCA GGA AGA GCC CGA GCC3' and Reverse primer: 5'GGG GCG GGG AGA TGA ATG3'. The PAC clone was digested by PstI and a Southern blot was performed using a $(\mathrm{CA})_{15}$ probe. A DNA fragment containing a CA repeat was identified, subcloned and sequenced. PCR primers were designed to flank the repeat sequence using the Primer 3

Table 1 Size and allele frequency of D8S2611 near the human PNOC locus on chromosome 8p21

\begin{tabular}{lll}
\hline Allele & Size $(b p)$ & Frequency \\
\hline 1 & 233 & 0.0046 \\
2 & 231 & 0.0183 \\
3 & 229 & 0.0766 \\
4 & 227 & 0.1247 \\
5 & 225 & 0.1133 \\
6 & 223 & 0.1510 \\
7 & 221 & 0.0870 \\
8 & 219 & 0.0766 \\
9 & 217 & 0.1236 \\
10 & 215 & 0.0229 \\
11 & 213 & 0.0206 \\
12 & 211 & 0.0492 \\
13 & 209 & 0.1053 \\
14 & 207 & 0.0011 \\
15 & 205 & 0.0252 \\
\hline
\end{tabular}

software program (Whitehead Institute/MIT Center for Genome Research). The PCR oligonucleotide primers were: N13 Forward 5'AGA CAT GGC CAG AAC AGC TT3' and N13 Reverse 5'CCA GCT CAT GTG GAT GCT TA3'.

Fifteen alleles were detected in 874 chromosomes of unrelated European Caucasian individuals. The observed heterozygosity frequency was 0.898. The size and the frequency of the alleles are summarised in Table 1 . The repeat was codominantly inherited in two three-generation families.

\section{Allelic association studies}

The CLUMP program was used to assess the evidence of allelic association between the marker loci and the disease locus. For each marker both the $\chi^{2}$ and $P$-value are shown for each of the four statistics that are produced by CLUMP (T1, T2, T3 and T4) (Table 2). None of these tests produced a statistically significant result for any of the four markers.

Pair-wise linkage disequilibrium was calculated between all pairs of markers using the EH program (Table 3). Both markers, D8S131 and D8S131P are upstream of exon 2 of the CHRNA2 gene and are themselves 9-20 kb apart. The two markers are in very strong linkage disequilibrium with each other as expected due to their close proximity. This finding provides further support that the negative association results between these two markers and schizophrenia are genuine.

\section{Discussion}

When selecting candidate genes for association studies of schizophrenia where the pathophysiology is unknown, the prior probability that any given gene is involved in the

Table 3 Pair-wise linkage disequilibrium between each pair of marker loci. The table shows the $P$-values obtained from the $\chi^{2}$ statistics calculated with the EH program

\begin{tabular}{llll}
\hline Markers & D8S131 & D8S131P & 1095 Mboll RFLP \\
\hline D8S2611 & 0.72 & 0.60 & 0.96 \\
D8S131 & & 0.0000 & 0.047 \\
D8S131P & & & 0.90 \\
\hline
\end{tabular}

Table 2 CLUMP test results for association between schizophrenia and alleles at polymorphic loci on chromosome 8p21-22 in a UK case-control sample. Where,T1: a straightforward Pearson's $\chi^{2}$ statistic of the 'raw' contingency table. T2: the $\chi^{2}$ statistic of a table with rare alleles grouped together to prevent small expected cell counts. T3: the largest of the $\chi^{2}$ statistics of $2 \times 2$ tables each of which compares one allele against the rest grouped together. T4: the largest of the $\chi^{2}$ statistics of all possible $2 \times 2$ tables comparing any combination of alleles against the rest. The RFLP is biallelic so only T1 results are presented

\begin{tabular}{|c|c|c|c|c|c|c|c|c|c|}
\hline & $T 1$ & $\begin{array}{l}\text { Asymptotic } \\
\text { P-value }\end{array}$ & $\begin{array}{l}\text { Empirical } \\
\text { P-value }\end{array}$ & $T 2$ & $\begin{array}{l}\text { Empirical } \\
\text { P-value }\end{array}$ & $T 3$ & $\begin{array}{l}\text { Empirical } \\
\text { P-value }\end{array}$ & $T 4$ & $\begin{array}{l}\text { Empirical } \\
\text { P-value }\end{array}$ \\
\hline D8S2611 & 15.4 & 0.35 & 0.35 & 13.0 & 0.40 & 5.1 & 0.26 & 9.2 & 0.36 \\
\hline D8S131 & 8.3 & 0.51 & 0.54 & 0.4 & 0.82 & 0.4 & 0.84 & 5.7 & 0.35 \\
\hline D8S131p & 13.6 & 0.48 & 0.40 & 3.8 & 0.89 & 2.7 & 0.56 & 7.6 & 0.32 \\
\hline 1095 Mboll RFLP & 0.3 & 0.59 & 0.61 & & & & & & \\
\hline
\end{tabular}


aetiology is usually very low. ${ }^{17,18}$ One way of increasing the prior probability is by examining the candidacy of genes that map in an interval that has already been implicated by prior evidence of genetic linkage. In this study, all the candidate genes map to chromosome $8 \mathrm{p} 21$, a region that has shown confirmed evidence of linkage with schizophrenia. Although the DNA polymorphisms studied are not expected to be the actual disease causing variants, their distance from the candidate genes does not exceed the limit for detectable $\mathrm{LD}$, which in an out-bred population, for a common and complex disorder is approximately $25 \mathrm{~kb} .{ }^{19}$ It is therefore reasonable to expect that they might demonstrate linkage disequilibrium with a disease-causing variant present in these genes, leading to allelic association between marker and disease. This theory is supported by our observation of strong linkage disequilibrium between the markers for the CHRNA2 gene, D8S131 and D8S131P. However, no significant differences in the allele frequencies of any of the markers studied near PNOC, CHRNA2 or NAT1 were observed in our population of schizophrenic patients in comparison with ethnically matched control individuals. The failure to demonstrate association is unlikely to be due to population stratification, since both groups of individuals were carefully matched for ethnicity and drawn from as ethnically a homogeneous population as possible. As more genes are identified, attention can focus on other candidate 8p21-22 genes using association studies.

\section{Acknowledgements}

We would like to thank the UK HGMP Resource Center for providing the PAC library. The research was funded by the Neuroscience Research Charitable Trust.

\section{References}

1 Brzustowicz LM, Honer WG, Chow EWC, et al: Linkage of familial schizophrenia to chromosome 13q32. Am J Hum Gene 1999; 65: 1096-1103.

2 Blouin JL, Dombroski BA, Nath SK, et al: Schizophrenia susceptibility loci on chromosomes $13 \mathrm{q} 32$ and $8 \mathrm{p} 21$. Nature Genet 1998; 20: 70-73.

3 Gurling HMD, Kalsi G, Brynjolfsson J, et al: Genome-wide linkage analysis confirms the presence of susceptibility loci for schizophrenia on chromosomes 1q32.2, 5q33.2 and 8p21-22 and provides support for linkage to schizophrenia on chromosomes 11q23.3-24 and 20q12.1-11.23. Am J Hum Genet 2001; in press.
4 Darland T, Heinricher MM, Grandy DK: Orphanin FQ/nociceptin: a role in pain and analgesia, but so much more. Trends Neurosci 1998; 21: $215-221$.

5 Freedman $\mathrm{R}$, Coon $\mathrm{H}$, Myles-Worsley $\mathrm{M}$, et al: Linkage of a neurophysiological deficit in schizophrenia to a chromosome 15 locus. Proc Nat Acad Sci USA 1997; 94: 587-592.

6 Wood S, Schertzer M, Yaremko ML: Identification of the human neuronal nicotinic cholinergic alpha 2 receptor locus, (CHRNA2), within an 8p21 mapped locus, by sequence homology with rat DNA. Som Cell Mol Genet 1995; 21: 147 - 150.

7 Matas N, Thygesen P, Stacey M, Risch A, Sim E: Mapping AAC1, AAC2 and AACP, the genes for arylamine $\mathrm{N}$-acetyltransferases, carcinogen metabolising enzymes on human chromosome $8 \mathrm{p} 22$, a region frequently deleted in tumours. Cytogenet Cell Genet 1997; 77: 290-295.

8 Spitzer R, Endicott J, Robins E: Research diagnostic criteria for a selected group of functional disorders, 3rd edition. New York: New York State Psychiatric Institute., 1978.

9 McGuffin P, Farmer A, Harvey I: A polydiagnostic application of operational criteria in studies of psychotic illness - development and reliability of the opcrit system. Arch Gen Psychiat 1991; 48: 764-770.

10 Spitzer R, Endicott J: The schedule for affective disorders and schizophrenia, lifetime version, 3rd edition. New York: New York State Psychiatric Institute, 1977.

11 Bell DA, Stephens EA, Castranio T, et al: Polyadenylation polymorphism in the acetyltransferase 1 gene (NAT1) increases risk of colorectal cancer. Cancer Res 1995; 55: 3537 - 3542.

12 Payton MA, Sim E: Genotyping human arylamine N-acetyltransferase type 1 (NAT1): the identification of two novel allelic variants. Biochem Pharmacol 1998; 55: 361-366.

13 Sham PC, Curtis D: Monte Carlo tests for associations between disease and alleles at highly polymorphic loci. Annals of Human Genetics 1995; 59 ( Pt 1): 97-105.

14 Terwilliger J, Ott J: Linkage disequilibrium between alleles at marker loci. Handbook of Human Genetic Linkage. Baltimore: Johns Hopkins University Press, 1994.

15 Ioannou PA, Jong PJ: Construction of Bacterial Artificial Chromosome libraries using the modified P1 (PAC) system. In: al. De, ed. Current Protocols in Human Genetics. NY: John Wiley and Sons, 1996.

16 Mollereau C, Simons MJ, Soularue P, et al: Structure, tissue distribution, and chromosomal localization of the prepronociceptin gene. Proc Nat Acad SCI USA 1996; 93: 8666-8670.

17 Owen MJ, Holmans P, McGuffin P: Association studies in psychiatric genetics. Mol Psychiat 1997; 2: 270-273.

18 Crowe RR: Candidate genes in psychiatry: an epidemiological perspective [see comments]. Am J Med Genet 1993; 48: 74-77.

19 Wijsman EM: Association vs linkage analysis in mental disorders. In: Blum K, Noble E, (eds): Handbook of Psychiatric Genetics 1997. 